\title{
Experimental exposure to toluene: further consideration of cresol formation in man*
}

\author{
W WOIWODE AND K DRYSCH \\ From Institut für Arbeits- und Sozialmedizin der Universität Tübingen, D-7400 Tübingen, $W$ Germany
}

ABSTRACT In two separate experiments 10 healthy men each were exposed at rest in an exposure chamber to about $200 \mathrm{ppm}$ toluene in the air. Hippuric acid, o-, m-, p-cresol, and phenol in urine were detected by capillary gas chromatography at the beginning and at the end of exposure, and at variable times after the cessation of exposure. In addition toluene in blood was determined at the same intervals. The results indicate that in addition to hippuric acid, o-, m-, and p-cresol are metabolites of toluene; the detoxication lasting 24 hours at least.

Formation of cresols after exposure to toluene was first suggested by Laham. ${ }^{1}$ Using elaborate analytical methods, $\mathrm{o}-$ and $\mathrm{p}$-cresol were detected in printing workers exposed to toluene. ${ }^{2-4}$ In a further investigation o-, m-, and p-cresol were found in an occupationally exposed group. ${ }^{5}$ Elucidation of a complete metabolic pattern is important in any discussion concerning the toxicity of toluene and the present investigation was set up to study this process further. Male volunteers were exposed to toluene experimentally in a chamber, and urinary metabolites were detected at intervals by means of capillary gas chromatography. This procedure has the advantage that environmental conditions may be standardised, and interference with other pollutants does not occur.

\section{Materials and methods}

EXPOSURE CHAMBER

To allow experimental exposures, a climatic chamber (Type 21, 5E/+2JV/10DV-EX, Weiss Company, Giessen) was established in our institute and specially modified in co-operation with the maker, the university building authorities, safety engineers, technicians, the insurance authorities, and the users. This comprehensive collaboration was necessary to ensure the detailed safety specification required for human experimental exposure. The degree of explosion protection was classed "EX-G3."6 The interior has an area of $8.96 \mathrm{~m}^{2}$ and a volume of $21.5 \mathrm{~m}^{3}$, and the chamber is isolated from adjacent rooms by a sluice.

*Dedicated to Professor Dr H Weichardt on his 65th birthday.

Received 3 April 1980

Accepted 1 May 1980
To minimise adsorption effects, the inner walls consist of stainless steel. The air conditioning has an operating temperature range from $+10^{\circ} \mathrm{C}$ to $40^{\circ} \mathrm{C}$ $\left( \pm 1.5^{\circ} \mathrm{C}\right)$ and a humidity range from $30 \%$ to $80 \%$ rel $( \pm 5 \%)$. For the experiments, $22^{\circ} \mathrm{C}$ and $45 \%$ rel humidity were set up. Feeding-, outgoing- and circulating air are led in isolated circuits. All ventilators are linked up with an emergency plant.

\section{DOSE-REGULATING EQUIPMENT}

The dose-regulating equipment had been recently constructed in our laboratory. The pollutant-for instance, an organic solvent-is nebulised directly into the circulating air and is passed through a sieve plate ceiling into the chamber. This homogenous dispersion gives a concentration profile, which is stable for hours. A concentration range from 5 to $1000 \mathrm{ppm}$ at solvent boiling points up to $160^{\circ} \mathrm{C}$ is available, and it is also possible to introduce stable concentrations of vapour mixtures and to make regular alterations to the concentration.

\section{MEASUREMENT OF THE VAPOUR \\ CONCENTRATION}

The measurement of vapour concentrations was carried out using three methods.

\section{Charcoal adsorption}

Charcoal adsorption of airborne toluene was performed over periods of one hour each, followed by gas-chromatographic head space analysis. ${ }^{\text {? }}$

Apparatus-Perkin-Elmer F-40 gas chromatograph designed for head space analysis.

Column-15\% Carbowax $1500+0.5 \%$ Triton X 305 on Chromosorb P AW, 80/100 mesh, stainless 
steel $2 \mathrm{~m} \times \frac{11}{8}$ od coupled with $5 \%$ SE 52 on Chromosorb G/AW, 80/100 mesh, stainless steel $2 \mathrm{~m} \times \frac{1}{8}$ od. All reagents (analytical grade) purchased from Merck, D-Darmstadt.

Carrier- $\mathrm{N}_{2}$, pressure 1.8 bar $(24 \mathrm{ml} / \mathrm{min})$.

Temperature-oven $110^{\circ} \mathrm{C}$ isothermal, flame ionisation detector $160^{\circ} \mathrm{C}$, injector $160^{\circ} \mathrm{C}$. One thousand microlitres injected automatically; water bath $60^{\circ} \mathrm{C}$, injection line $170^{\circ} \mathrm{C}$.

\section{Control by detection tubes 8}

Spot checks were carried out using detection tubes "toluene 5a" purchased from Dräger, D-Lübeck. As shown previously, ${ }^{17}$ this method is highly accurate if critically applied.

\section{Infrared spectrometry}

Direct control monitoring was achieved by infrared spectrometry. A standard infrared spectrometer was equipped with a gas cell variable in optical path length from 0.75 to $20.25 \mathrm{~m}$. The ambient air to be analysed was dried by passage through magnesium perchlorate and sucked through the detector cell by means of a membrane pump with a flow rate of about $15 \mathrm{l} / \mathrm{hr}$. With a scale expansion device and an auxiliary recorder a measuring range from $10^{-2}$ to $10^{4} \mathrm{ppm}$ is yielded. For calibration known amounts of the pollutants are injected directly into the gas cell with a microlitre syringe. The accuracy of repeated detector signals is better than $10 \%$.

Apparatus-Infrared spectrometer Acculab II TM, Beckman; 20 meter multipass gas cell, Wilks; auxiliary recorder, Servogor; membrane pump AL 17, Neuberger; magnesium perchlorate, analytical grade, Merck.

Measuring parameters for toluene - analytical wavelength $13.7 \mu=730 \mathrm{~cm}^{-1}$; pathlength $5.25 \mathrm{~m}$, scale expansion $\times 1$.

The concentration profile of one experimental exposure and further experimental details are given in fig 1 .

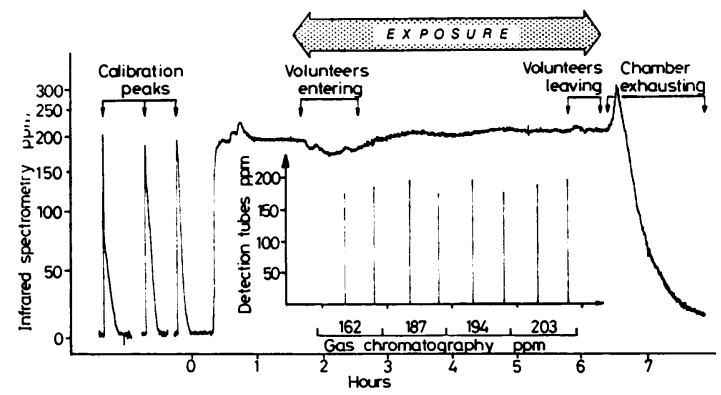

Fig 1 Concentration profile of toluene during one experimental exposure.
EXPERIMENTAL EXPOSURE TO TOLUENE

According to the methods outlined above, atmospheres containing $200 \mathrm{ppm}$ toluene were set up and controlled. In two experiments 10 healthy male volunteers each were exposed at rest for four hours. Blood and urine spot samples were taken before starting the experiment, at the end of a four-hour exposure, and after a further four, 20, and 44 hours. The subjects were allowed to drink during exposure.

DETECTION OF METABOLITES IN URINE

Density of the urine samples was checked pyknometrically. o-, m-, p-cresol and phenol were determined by capillary gas chromatography as described previously. ${ }^{5}$ For the analysis of hippuric acid, m-methyl-hippuric acid as an internal standard was added to $1 \mathrm{ml}$ urine. The $\mathrm{pH}$ was set to 2 with hydrochloric acid, and the sample was extracted twice with $2 \mathrm{ml}$ ethyl acetate. The organic layer was separated by centrifugation and dried over sodium sulphate and the solvent removed under a slow stream of nitrogen. After the addition of $1 \mathrm{ml} 3 \mathrm{M}$ hydrogen chloride solution in isopropanol, esterification was carried out at $110^{\circ} \mathrm{C}$ for one hour. The solvent was again removed and the sample redissolved in $200 \mu \mathrm{l}$ dichloromethane. One microlitre of the final solution was injected for gas-chromatographic analysis.

During sample preparation and derivatisation, both hippuric acid and m-methyl-hippuric acid behave similarly. Before the experiment began we ensured that m-methyl-hippuric acid does not occur in normal people or in people exposed to toluene.

Apparatus-Carlo Erba Gas-Chromatograph 2150 equipped with flame ionisation detector (FID) and Spectra Physics Integrator System I. Glass capillary: $25 \mathrm{~m} \times 0.3 \mathrm{~cm}$ id, coated with Silicone OV 225 purchased from Merck. Carrier: hydrogen, pressure 0.6 bar. Temperature of injector and FID: $275^{\circ} \mathrm{C}$. $1 \mu \mathrm{l}$ (about 5 nano moles) is injected at a split rate of $1: 30$. Analysis was carried out in isothermal mode at $200^{\circ} \mathrm{C}$.

DETECTION OF TOLUENE IN BLOOD

Toluene in blood was analysed by a gas-chromatographic head space technique. ${ }^{7}$ About $1 \mathrm{ml}$ whole blood was heparinised and analysed according to the method given above for head space analysis of charcoal adsorbates.

\section{Results and discussion}

Experimental exposure to toluene at the MAK-value of $200 \mathrm{ppm}^{9}$ was performed for four hours with 10 subjects. The concentration profile was stable and the presence of additional pollutant could be exclu- 
Table 1 Common mean values for toluene in blood and urinary metabolites from two exposure experiments

\begin{tabular}{|c|c|c|c|c|c|c|}
\hline & & Before exposure & After 4 hours' exp & 4 hours after exp & 20 hours after exp & 44 hours after exp \\
\hline $\begin{array}{l}\text { Toluene in } \\
\text { blood } \\
\mu \mathrm{g} / 1\end{array}$ & $\begin{array}{l}\mathbf{x} \\
\mathbf{s} \\
\mathbf{n}\end{array}$ & $\frac{10}{20}$ & $\begin{array}{c}755 \cdot 3 \\
159 \cdot 6 \\
20\end{array}$ & $\begin{array}{l}58 \cdot 4 \\
27 \cdot 7 \\
20\end{array}$ & $\begin{array}{c}21 \cdot 9 \\
8 \cdot 8 \\
20\end{array}$ & $\begin{array}{l}-\ddagger \\
-\ddagger \\
-\ddagger\end{array}$ \\
\hline $\begin{array}{l}\text { Hippuric acid } \\
\text { in urine } \\
\mathrm{g} / \mathrm{l}\end{array}$ & $\begin{array}{l}\mathbf{x} \\
\mathbf{s} \\
\mathbf{n}\end{array}$ & $\begin{array}{c}0.823 \\
0.518 \\
16\end{array}$ & $\begin{array}{c}4 \cdot 208 \\
2 \cdot 589 \\
19\end{array}$ & $\begin{array}{c}1.663 \\
0.977 \\
19\end{array}$ & $\begin{array}{c}1 \cdot 074 \\
0.519 \\
18\end{array}$ & $\begin{array}{l}0.680 \\
0.688 \\
5\end{array}$ \\
\hline $\begin{array}{l}\text { o-Cresol } \\
\text { in urine } \\
\mathrm{mg} / 1\end{array}$ & $\begin{array}{l}\mathbf{x} \\
\mathbf{s} \\
\mathbf{n}\end{array}$ & $\begin{array}{c}0 \cdot 159 \\
0 \cdot 110 \\
18\end{array}$ & $\begin{array}{c}1.603 \\
0 \cdot 796 \\
19\end{array}$ & $\begin{array}{c}1.400 \\
0.688 \\
19\end{array}$ & $\begin{array}{c}0.495 \\
0.236 \\
18\end{array}$ & $\begin{array}{l}0.130 \\
0.048 \\
5\end{array}$ \\
\hline $\begin{array}{l}\text { m-Cresol } \\
\text { in urine } \\
\mathrm{mg} / \mathrm{l}\end{array}$ & $\begin{array}{l}\mathbf{x} \\
\mathbf{s} \\
\mathbf{n}\end{array}$ & $\begin{array}{l}<0 \cdot 2^{*} \\
{ }_{18}^{\dagger}\end{array}$ & $\begin{array}{c}0.570 \\
0 \cdot 255 \\
19\end{array}$ & $\begin{array}{c}0.599 \\
0.316 \\
18\end{array}$ & $\begin{array}{c}0.527 \\
0 \cdot 324 \\
18\end{array}$ & $\begin{array}{l}<0 \cdot 2^{*} \\
-t\end{array}$ \\
\hline $\begin{array}{l}\text { p-Cresol } \\
\text { in urine } \\
\mathrm{mg} / 1\end{array}$ & $\begin{array}{l}\mathbf{x} \\
\mathbf{s} \\
\mathbf{n}\end{array}$ & $\begin{array}{l}31 \cdot 206 \\
17 \cdot 780 \\
16\end{array}$ & $\begin{array}{c}39 \cdot 590 \\
24 \cdot 673 \\
19\end{array}$ & $\begin{array}{l}40 \cdot 968 \\
26 \cdot 578 \\
19\end{array}$ & $\begin{array}{l}39 \cdot 965 \\
23 \cdot 540 \\
17\end{array}$ & $\begin{array}{c}40 \cdot 275 \\
30 \cdot 376 \\
4\end{array}$ \\
\hline $\begin{array}{l}\text { Phenol } \\
\text { in urine } \\
\mathrm{mg} / 1\end{array}$ & $\begin{array}{l}\mathbf{x} \\
\mathbf{s} \\
\mathbf{n}\end{array}$ & $\begin{array}{l}4 \cdot 869 \\
2 \cdot 282 \\
16\end{array}$ & $\begin{array}{c}3 \cdot 483 \\
2 \cdot 453 \\
18\end{array}$ & $\begin{array}{l}4 \cdot 017 \\
4 \cdot 169 \\
18\end{array}$ & $\begin{array}{l}6 \cdot 900 \\
4 \cdot 076 \\
17\end{array}$ & $\begin{array}{l}5 \cdot 033 \\
1 \cdot 966 \\
3\end{array}$ \\
\hline $\begin{array}{l}\text { Density of } \\
\text { urine } \\
\mathrm{g} / \mathrm{l}\end{array}$ & $\begin{array}{l}\mathbf{x} \\
\mathbf{s} \\
\mathbf{n}\end{array}$ & $\begin{array}{c}1010 \cdot 8 \\
6 \cdot 3 \\
18\end{array}$ & $\begin{array}{c}1007 \cdot 7 \\
5 \cdot 4 \\
19\end{array}$ & $\begin{array}{l}1011 \cdot 4 \\
6 \cdot 1 \\
18\end{array}$ & $\begin{array}{c}1011 \cdot 8 \\
4 \cdot 4 \\
17\end{array}$ & $\begin{array}{l}1014 \cdot 8 \\
7 \cdot 6 \\
5\end{array}$ \\
\hline
\end{tabular}

* Below detection limit. †Not computable. $¥$ Missing data.

Table 2 Results of linear regression $Y=A+B \div X$

\begin{tabular}{|c|c|c|c|c|c|}
\hline Parameter combination $X / Y$ & Correlation coefficient & $N$ & $A$ & $\boldsymbol{B}$ & Significance $<2 p$ \\
\hline Toluene/hippuric acid & 0.6984 & 70 & 1.070 & $4 \cdot 09410^{-3}$ & 0.001 \\
\hline Toluene/o-cresol & 0.5531 & 72 & 0.634 & $1 \cdot 33710^{-3}$ & 0.001 \\
\hline Toluene/m-cresol & 0.2296 & 71 & 0.430 & $2.04910^{-4}$ & 0.05 \\
\hline Hippuric acid/o-cresol & $0 \cdot 7036$ & 74 & $0 \cdot 334$ & 0.293 & 0.001 \\
\hline Hippuric acid/m-cresol & $0 \cdot 2284$ & 74 & $0 \cdot 398$ & 0.035 & 0.05 \\
\hline Hippuric acid/p-cresol & 0.3292 & 72 & 30.958 & 3.920 & 0.01 \\
\hline o-Cresol/m-cresol & 0.5067 & 76 & $0 \cdot 294$ & $0 \cdot 191$ & 0.001 \\
\hline Phenol/urine density & 0.4510 & 69 & $1006 \cdot 756$ & 0.757 & 0.001 \\
\hline
\end{tabular}

$\mathbf{N}=$ Number of single measuring values. $\mathbf{A}=$ Intercept. $\mathbf{B}=$ Slope

ded. There was no statistical difference between the results obtained from the two experiments, so they are combined in table 1 .

The correlation between the excretion of the various metabolites was shown by linear regression. Table 2 shows the results of this analysis; no correction for urine density is given.

The mean values for all metabolites in the urine increased after four hours' exposure except phenol and urine density. The subjects were allowed to drink during exposure, which accounts for the decrease in urine density. As phenol is not involved in the detoxication of toluene but only to urine density, it is to be expected that phenol excretion would also decrease.

Hippuric acid as a metabolite of toluene ${ }^{10-14}$ is a highly suitable parameter for the biological monitoring of toluene. From the present results it can be estimated that a concentration range from $2 \mathrm{~g} / 1$ to $6 \mathrm{~g} / \mathrm{l}$ (mean value $4 \mathrm{~g} / \mathrm{l}$ ) at a urine density of about $1012 \mathrm{~g} / \mathrm{l}$ indicates exposure near the MAK-value of $200 \mathrm{ppm}$.

In addition to hippuric acid, o-, m-, and p-cresol are also metabolites of toluene, the formation taking place concomitantly. Participation of p-cresol in toluene metabolism could not be shown clearly, as the increase during exposure is small compared with the normal range. In fig 2 the excretion of metabolites after correction for urine density of $1012 \mathrm{~g} / \mathbf{1}^{15}$ is shown. The increase of all urinary metabolites becomes more obvious after correction. The formation of o-cresol is due entirely to toluene metabolism; values $>1 \mathrm{mg} / \mathrm{l}$ at a urine density of about 1012 indicate exposure near the MAK-value.

Analysis of hippuric acid and o-cresol by capillary gas chromatography is advantageous for the bio- 


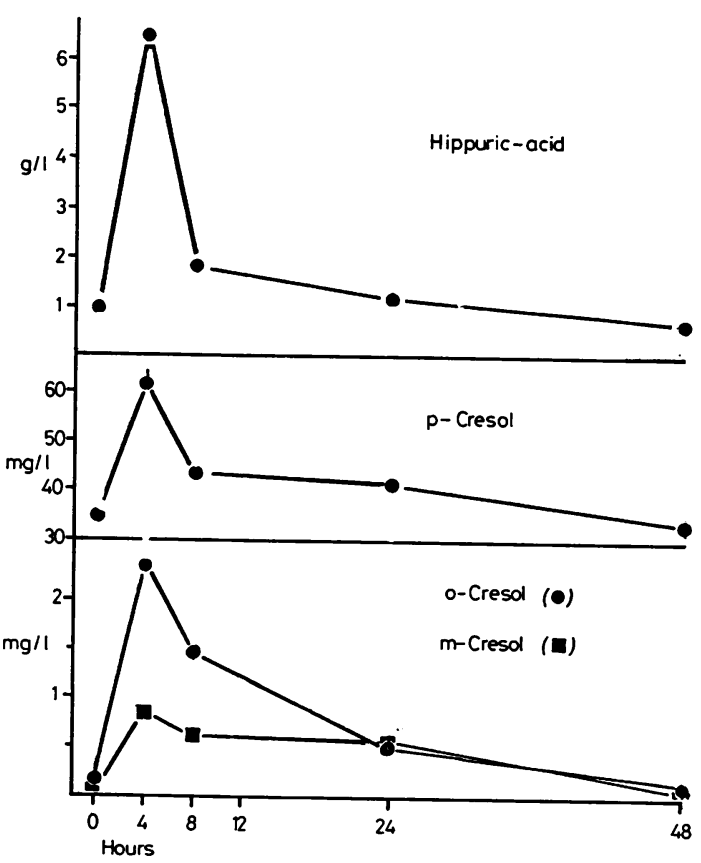

Fig 2 Excretion of urinary metabolites of toluene, corrected for mean density of $1012 \mathrm{~g} / \mathrm{l}$. Exposure interval four hours.

logical monitoring of even large numbers of samples: the method described is fast, simple, and accurate, requiring spot samples of urine only, and moreover it can be automated. If the results of urine analysis indicate exposure near the MAK-value, this may be determined by a personal air sampling technique developed previously. ${ }^{16}$

The secretarial help of Ms Ludwig is gratefully acknowledged. Gas-chromatographic analysis was carried out by Ms Fritzsche. We thank Mr Konietzko for the medical management of the exposure experiments. Parts of the data system were financially supported by Deutsche Forschungsgemeinschaft.

\section{References}

${ }^{1}$ Laham S. Metabolism of industrial solvents. Industrial Medicine and Surgery 1970;39:61-4.

2 Szadkowski D, Pett R, Angerer J, Manz A, Lehnert G. Chronische Lösungsmittelbelastung am Arbeitsplatz. II
Schadstoffspiegel im Blut und Metabolitenelimination im Harn in ihrer Bedeutung als Überwachungskriterien bei toluolexponierten Tiefdruckern. Internationales Archiv für Arbeitsmedizin 1973;31:265-76.

3 Angerer J. Chronische Lösungsmittelbelastung am Arbeitsplatz. V Chromatographische Methoden zur Bestimmung von Phenolen im Harn. Int Arch Environ Health $1979 ; 42: 257-68$.

4 Pfäffli P, Savolainen H, Kalliomäki P-L, Kalliokoski P. Urinary o-cresol in toluene exposure. Scand $J$ Work Environ Health 1979;5:286-9.

${ }^{5}$ Woiwode W, Wodarz R, Drysch K, Weichardt H. Metabolism of toluene in man: gas-chromatographic determination of o-, m- and p-cresol in urine. Arch Toxicol 1979;43:93-8.

- VDE-Bestimmung 0165/8.69. Bestimmung für die Errichtung elektrischer Anlagen in explosions-gefährdeten Betriebsstätten. Berlin: VDE-Verlag GmbH, 1969.

${ }^{7}$ Bencsáth FA, Drysch K, Weichardt H. Gaschromatographische-massenspektrometrische Identifizierung und automatisierbare Bestimmung von flüchtigen organischen Schadstoffen durch Headspace-Technik. Stockholm: International Symposium on the Control of Air Pollution in the Working Environment, 1977:293.

${ }^{8}$ Leichnitz K. Das Prüfröhrchenverfahren und seine Entwicklungstendenzen. Chemiker Zeitung 1973;97:63845.

- Henschler D. Gesundheitsschädliche Arbeitsstoffe. Toxikologisch-arbeitsmedizinische Begründung von MAKWerten. Weinheim: Verlag Chemie GmbH, 1978.

${ }^{10}$ Bardodej Z. Beurteilung der Benzol- und PhenolGefährdung mit dem Phenoltest. Arbeitsmedizin Sozialmedizin Arbeitshygiene 1968;3:141-2.

11 Ikeda M, Ohtsuji H. Significance of urinary hippuric acid determination as an index of toluene exposure. $\mathrm{Br} J$ Ind Med 1969;26:244-6.

12 Ogata M, Tomokuni $\mathrm{K}$, Takatsuka Y. Urinary excretion of hippuric acid and $\mathrm{m}$ - or p-methylhippuric acid in the urine of persons exposed to vapours of toluene and $\mathrm{m}$ or p-xylene as a test of exposure. Br J Ind Med 1970; 27:43-50.

13 Ogata M, Fujii T. Urinary excretion of hippuric acid and m-methylhippuric acid after administration of toluene and m-xylene mixture to rats. Int Arch Occup Environ Health $1979 ; 43: 45-51$.

14 Veulemans H, Masschelein R. Experimental human exposure to toluene. III Urinary hippuric acid excretion as a measure of individual solvent uptake. Int Arch Environ Health 1979;43:53-62.

${ }^{15}$ Hinsberg K. In: Lang, K, Lehnartz E. Hoppe-Seyler/ Thierfelder. Handbuch der physiologisch- und patholo: gisch-chemischen Analyse. 10th ed. Vol 5. BerlinSpringer Verlag, 1953: 181.

16 Bencsáth FA, Drysch K, List D, Weichardt H. Analysis of volatile air pollutants by charcoal adsorption with subsequent gas chromatographic head space analysis by desorption with benzylalcohol. Part I Method and applications. Überlingen: Perkin-Elmer, 1978. (Angew Chromatographie No 32 E.)

17 Weichardt H, Woiwode W, Drysch K, Bencsáth FA. Gaschromatographische Bestimmung von Toluol in der Luft und Prüfröhrchenmethode-ein kritischer Vergleich. Lübeck: Drägerwerk, 1980. (Draegerheft 316.) 